\title{
Implementasi Teori Psikologi Kognitif Ibnu Qayyim dalam Meluruskan Pernyataan Radikalisme di Indonesia
}

\author{
Rico Febriansyah ${ }^{1 *}$ \\ ${ }^{1}$ UIN Raden Fatah Palembang, Indonesia
}

\begin{abstract}
Abstrak: Penelitian ini bertujuan untuk meluruskan pernyataan radikalisme di Indonesia dengan implementasi teori psikologi Ibnu Qoyyim. Metode penelitian yang digunakan adalah kualitatif dengan pendekatan kepustakaan. Penelitian ini menyimpulkan bahwa peran psikologi dalam mempengaruhi pikiran dan pembentukan perilaku sangat dominan dalam proses meluruskan pernyataaan radikalisme sekaligus dalam upaya menangkal paham radikalisme di masyarakat Indonesia. Pernyataan radikalisme sering dikaitkan dengan agama Islam, padahal Islam sendiri tidak mengenal konsep radikalisme itu, sehingga diperlukan sebuah langkah pergerakan dalam hal meluruskan pernyataan radikalisme melalui implementasi teori psikologi kognitif Ibnu Qayyim yang merupakan konsep pola dalam rangka pembentukan sikap dan perilaku seseorang, oleh karena itu teori ini akan sangat berguna sebagai langkah preventif untuk menangkal radikalisme dan membentuk pikiran masyarakat yang benar dalam mengartikan radikalisme tersebut.
\end{abstract}

Kata Kunci: radikalisme, psikologi kognitif, Islam

\begin{abstract}
This study aims to straighten out the statement of radicalism in Indonesia with the implementation of Ibn Qoyyim's psychological theory. The research method used is qualitative with a library approach. This study concludes that the role of psychology in influencing thoughts and behavior formation is very dominant in the process of straightening statements of radicalism as well as in an effort to counteract radicalism in Indonesian society. Statements of radicalism are often associated with Islam, even though Islam itself does not recognize the concept of radicalism, so a movement step is needed in terms of straightening out statements of radicalism through the implementation of Ibn Qayyim's cognitive psychology theory which is a pattern concept in the context of forming one's attitudes and behavior, therefore the theory of This will be very useful as a preventive measure to ward off radicalism and form the correct public mind in interpreting radicalism.
\end{abstract}

Keywords: radicalism, cognitive psychology, Islam

\section{Pendahuluan}

Fenomena yang sedang terjadi dalam lingkaran kekuasaan saat ini adalah dikenalnya kata "radikal". Kata radikal ini seperti artis baru yang muncul kepermukaan dan langsung terkenal di berbagai penjuru Indonesia. Pernyataan radikal sering kali ditujukan kepada agama Islam, sehingga sering kali kata Islam disandingkan dengan kata radikal yaitu menjadi Islam radikal. Hal ini yang membuat umat Islam bersuara untuk menyatakan ketidakadilan terhadap pernyataan yang sematasemata Islam sebagai agama yang radikal.

\footnotetext{
* Corresponding Author: Rico Febriansyah (ricofebriansyah3@gmail.com). UIN Raden Fatah Palembang, Indonesia
} 
Menurut Kamus Besar Bahasa Indonesia (KBBI), radikal secara politik mengandung arti "amat keras" menuntut perubahan Undang-Undang atau Pemerintahan. Sedangkan radikalisme mengandung arti "paham atau aliran yang menginginkan perubahan atau pembaharuan sosial dan politik dengan cara kekerasan atau drastis". Oleh karena itu, sehingga radikalisme sendiri berkaitan dengan paham yang menginginkan perubahan dengan cara kekerasan.

Dengan demikian, antara radikal dan radikalisme adalah dua kata yang berbeda dan keduanya bagian dari gejala umum yang bisa terjadi dalam suatu masyarakat yang beragam, baik sosial, politik, budaya maupun agama. Jika radikal adalah perubahan secara mendasar, pokok, dan esensial yang berkonotasi baik atau netral. Sedangkan radikalisme merupakan paham untuk melakukan tindakan-tindakan keras, ekstrim, dan anarkis sebagai wujud penolakan terhadap gejala yang dihadapi serta memiliki implikasi kerusakan atau negatif (Baidhowi, 2017).

Radikalisme sudah menjadi perhatian serius, Pemerintah satu suara untuk membasminya dikarenakan mengandung konotasi yang negatif, sehingga Presiden Jokowi yang baru saja melantik pembantunya di Kabinet Indonesia Maju bergerak cepat. Berbagai pernyataan radikalisme menjadi sangat populer yang kemudian memunculkan pro dan kontra di masyarakat. Hal yang membuat umat Islam semakin bersuara lantang yaitu ketika Menteri Agama beberapa kali mengeluarkan pernyataan radikalisme dengan mengaitkan dengan orang yang bernikab dan bercelana cingkrang, pernyataan frontal Menag ini kemudian memberikan hikmah bagi umat Islam untuk dapat meluruskan pernyataan radikalisme ini.

Islam tanpa harus menjelaskan ada atau tidaknya paham radikalisme dalam agama Islam sebetulnya sudah terjawab secara tersirat dari berbagai dalil Allah Swt di antaranya Q.S al-Anfal ayat 61. Dalil tersebut membantah bahwa Islam sebagai agama kekerasan yang diidentikan dengan radikalisme. Sebetulnya Islam itu sendiri lahir condong kepada kedamaian sehingga ada banyak dalil dalam Al-Qur'an yang menolak segala bentuk kekerasan baik itu larangan pembunuhan dalam Q.S al-Maidah ayat 32, toleransi agama seperti dalam Q.S al-Kafirun sampai dengan berdakwah dengan hikmah yang terdapat dalam Q.S an-Nahl ayat 125 .

Sehingga pernyataan Islam-Radikal dinilai tidak tepat apalagi dikaitkan dengan simbol agama, karena Islam sendiri tidak menganjurkan segala bentuk kekerasan. Islam mengenal ideologi rahmatan lil 'alamin, Islam sebagai agama menjadi sumber utama seseorang dikala mengalami problem dalam hidupnya. Setiap agama mempunyai tata cara atau ritual tersendiri yang lahir dari kombinasi antara kehidupan spritual dan materialistik. Agama merupakan instrumen dalam kehidupan sosial manusia (Berger, 1991; Ma'mun, 2013) demikian juga Islam. Oleh karena itu, celana cingkrang dan nikab sudah menjadi bagian hak seorang yang beragama Islam sehingga tidak tepat jika menjadi tolak ukur orang ekstrimis atau radikalis. Apabila hal itu dilakukan maka akan bertentangan dengan hak asasi manusia yang diatur oleh konstitusi.

Dengan melihat berbagai fenomena di atas, pernyataan radikalisme sering kali tidak tepat sasaran yang pada akhirnya mempengaruhi stigma masyarakat luas terhadap radikalisme yang condong kepada Islam, padahal konsep Islam sendiri tidak mengenal radikalisme yang dimaksud. Hal ini semakin sangat tidak sesuai dengan konsep kebhinekaan Indonesia ketika radikalisme ini kemudian membumihanguskan hak kebebasan beragama, seperti melarang pemakaian nikab dan 
celana cingkrang yang sudah termasuk bagian dari hak asasi yang dilindungi oleh konstitusi selama tidak bertentangan dengan kehidupan berbangsa dan bernegara.

\section{Metode Penelitian}

Metode yang digunakan adalah kualitatif dengan kepustakaan. Data dikumpulkan melalui dokumen yang bersumber dari Al-Qur'an dan Hadis serta referensi lainnya yang relevan.

\section{Hasil Penelitian dan Pembahasan}

\section{Persepsi Masyarakat terhadap Radikalisme}

Fenomena kata "radikalisme" di Indonesia saat ini sedang menjadi makanan sehari-hari, hal ini tidak terlepas dari peran media dalam mengangkat isu radikalisme ini. Peran media sangat mempengaruhi persepsi masyarakat terhadap suatu isu, hal inipun terjadi dalam kasus radikalisme. Namun sangat disayangkan sering kali paham radikalisme yang negatif sering kali ditujukan kepada agama Islam. Padahal agama Islam tidak pernah mengajarkan paham radikalisme ini, radikalisme sangat bertolak belakang dengan konsep Islam sebagai agama kasih sayang bagi seluruh alam.

Radikalisme dalam segala halnya juga merupakan bentuk pengejawantahan dari terorisme, dikarenakan sama-sama paham yang bertitik berat pada kekerasan akan tetapi terorisme sudah mengandung pengertian dan kriteria yang jelas diatur oleh Undang-Undang Nomor 15 Tahun 2003 tentang Pemberantasan Tindak Pidana Terorisme sedangkan radikalisme belum dijelaskan secara tegas sehingga menyebabkan stigma yang luas di masyarakat terhadap isu radikalisme yang pada akhirnya menimbulkan keresahan di tengahtengah masyarakat (Indonesia, 2003).
Pola berpikir masyarakat terhadap radikalisme juga dipengaruhi dari pernyataan pemerintah yang tampak menyamakan kriteria radikalisme ini dengan terorisme, yang akhirnya masyarakat beranggapan bahwa radikalisme itu adalah paham yang negatif, padahal radikalisme juga mengandung arti yang positif jika ditempatkan pada hal yang positif. Mitsuo Nakamura misalnya, menyebut bahwa Nahdlatul Ulama (NU) adalah organisasi yang berwatak tradisionalisme radikal (Nakamura, 1981). Istilah radikal dipilih oleh Mitsuo Nakamura untuk menggambarkan bahwa NU adalah organisasi yang otonom dan independen, bukan derivasi dari organisasi yang lain (Baidhowi, 2017).

Merebaknya fenomena kata "radikalisme" ini juga disebabkan banyaknya kasus terorisme yang terjadi di Indonesia, karena radikalisme selalu diidentikkan dengan terorisme. Sehingga radikalisme sering muncul kepermukaan ketika terorisme itu terjadi. Kejadian terorisme saat ini sedang menjadi perhatian serius dikarenakan jaringanya yang luas, hal ini diperkuat oleh Sidratahta seorang peneliti ahli dari Badan Nasional Penanggulangan Terorisme (BNPT) yang menyatakan ada 2,7 juta orang Indonesia terlibat dalam serangkaian serangan teror. Bahkan jumlah itu belum termasuk pengikut dan simpatisan jaringan teroris (Mahdi, 2016).

Fenomena radikalisme di Indonesia ini memberikan peringatan bahwa segala bentuk kekerasan sesungguhnya bukanlah bagian dari ajaran agama Islam maupun Pancasila, maka diperlukan sebuah solusi dalam meluruskan pernyataan radikalisme maupun menangkal paham radikalisme yang negatif tersebut di Indonesia. Oleh karena itu, dari telaah di atas dapat digaris bawahi diperlukan sebuah teori dalam memecehakan persoalan radikalisme dengan 
konsep pola berpikir dan perilaku yang memberi edukasi dalam upaya meluruskan pernyataan radikalisme di Indonesia.

\section{Teori Psikologi Kognitif Ibnu Qayyim}

Radikalisme merupakan sebuah paham, sehingga sangat erat kaitannya dengan pemikiran dengan berbagai tingkatan sampai dengan proses ingin melakukannya. Oleh karena itu, sangat berkaitan dengan pengetahuan yang mempengaruhi pikiran, Ibnu Qayyim menyampaikan pengetahuan tentang hierarki atau tahapan pembentuk perilaku seorang dapat juga kita manfaatkan untuk mengantisipasi godaan setan. Setan memengaruhi kita pertama kali dari lintasan pikiran. Lintasan hati yang sering muncul kemudian menjadi termemorikan dalam benak kita. Setelah termemorikan, ajakan setan tersebut lamakelamaan akan menjadi gagasan, begitu seterusnya.

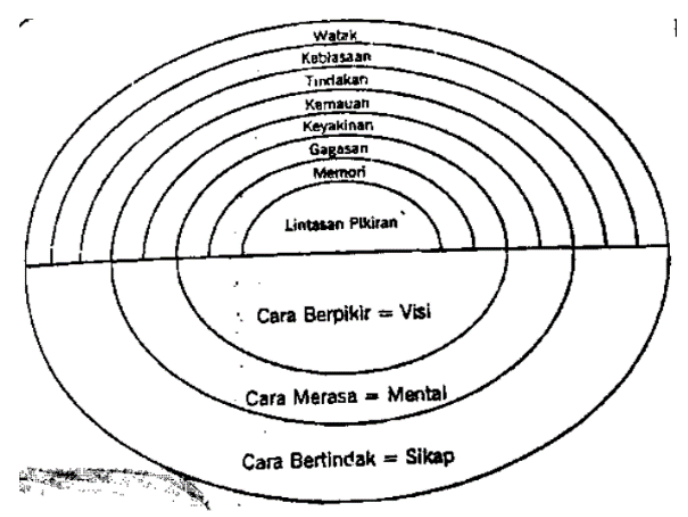

Gambar 1. Konsep Teori Psikologi Kognitif Ibnu Qayyim

Dalam Hadis dikatakan bahwa pandangan mata adalah salah satu anak panah setan. Dari pandangan mata, akan melahirkan lintasan pikiran. Jika lintasan pikiran ini tidak dapat dicegah, lamakelamaan akan terekam oleh memori. Jika tidak juga diantisipasi, godaan setan itu semakin sulit ditolak pada tahapan berikutnya. Oleh karena itu, Teori Psikologi Kognitif ini setidaknya sebagai upaya preventif dalam membantu meluruskan pernyataan radikalisme di Indonesia dengan berbagai konsep pola dengan tujuan sebagai berikut; (1) membentuk pikiran masyarakat terhadap hakikat pernyataan radikalisme yang dimaksud, (2) sebagai pola dalam upaya mencegah paham radikalisme di masyarakat, (3) bentuk penyaringan paham radikalisme dalam pikiran masyarakat sehingga paham ini benar-benar sesuai dengan hakikatnya, dan (4) upaya dalam meluruskan pernyataan radikalisme di masyarakat, sehingga tidak mendiskriminasikan Islam.

\section{Kesimpulan}

Penelitian ini menyimpulkan bahwa peran psikologi dalam mempengaruhi pikiran dan pembentukan perilaku sangat dominan dalam proses meluruskan pernyataaan radikalisme sekaligus dalam upaya menangkal paham radikalisme di masyarakat Indonesia. Pernyataan radikalisme sering dikaitkan dengan agama Islam, padahal Islam sendiri tidak mengenal konsep radikalisme itu, sehingga diperlukan sebuah langkah pergerakan dalam hal meluruskan pernyataan radikalisme melalui implementasi Teori Psikologi Kognitif Ibnu Qayyim yang merupakan konsep pola dalam rangka pembentukan sikap dan perilaku seseorang, oleh karena itu teori ini akan sangat berguna sebagai langkah preventif untuk menangkal radikalisme dan membentuk pikiran masyarakat yang benar dalam mengartikan radikalisme tersebut.

\section{Daftar Pustaka}

Baidhowi, B. (2017). Islam Tidak Radikalisme dan Terorisme. Law Research Review Quarterly, 3(2), 197-218.

Berger, P. L. (1991). Langit Suci Agama Sebagai Realitas Sosial (Hartono (ed.)). LP3ES.

Indonesia, R. (2003). Undang-Undang Nomor 15

Tahun 2003 Tentang Pemberantasan Tindak

Pidana Terorisme. Lembaran Negara Tahun.

Ma'mun, S. (2013). Relevansi agama dan alam 
dalam pandangan aliran kebatinan dayak indramayu. Kontekstualita: Jurnal Penelitian Sosial Keagamaan, 28(2), 117-126.

Mahdi, I. (2016). BNPT Sebut Ada 2,7 Juta Orang Indonesia Terlibat Terorisme. Tempo.Co. https://nasional.tempo.co/read/737905/bnptsebutada-27-juta-orang-indonesia-terlibatterorisme

Nakamura, M. (1981). The radical traditionalism of the Nahdlatul Ulama in Indonesia: A personal account of the 26th National Congress, June 1979, Semarang. Japanese Journal of Southeast Asian Studies, 19(2), 187-204. 